\title{
Organizational and economic mechanisms of qualitative modeling of sustainable development of the enterprise
}

\author{
Olga Maslak ${ }^{1}$, Natalya Grishko ${ }^{1}$, Mykhailo Odintsov ${ }^{1}$, Yaroslava Yakovenko $^{1, *}$, and Khatuna Buchashvili ${ }^{2}$
}

${ }^{1}$ Kremenchuk Mykhailo Ostrohradskyi National University, Department of Economics, 20 Pershotravneva, Kremenchuk, 39600, Ukraine ${ }^{2}$ Majorel Georgia LLC, Vake-Saburtalo District, 34 I. Chavchavadze Ave., 2 Floor, 0179, Tbilisi, Georgia

\begin{abstract}
In modern conditions the successful operation of enterprises and maintaining the sustainability of their development depend on the adaptive model of strategic management of the enterprise. The development of such a model using traditional econometric approaches was proposed in the paper. It was suggested by the authors to take into account the prerequisites and specifics of operating activities using the method of PLS (Partial Least Squares), when it is possible to find several important (result) indicators out by the transition from the original set of features to the set of major components of a smaller dimension while maintaining causal relationships allows. The PLS-PM model of sustainable development of the mining enterprise as a complex economic system was done. The essence of latent variables and the relationship between them were identified and substantiated as well as the numerical modelling was performed using the methods of scientific generalization and abstraction.
\end{abstract}

\section{Introduction}

The PLS-PM tool (Partial Least Squares Path Modeling) allows to build complex models of causal interactions between latent variables on the basis of componentoriented approach as well as to evaluate general factor models that can be part of multicomponent analysis in addition to this $[4,6,12]$. Moreover, the use of PLS-PM modeling can turn the interaction between implicit indicators and generate predictive values of quantitative changes off.

The stages of identifying model variables and determining the relationships between them proceed without the involvement of the software. The need for the use of software products arises at the stage of determining development scenarios, when direct calculation of the characteristics of the built model are in progress. The researchers are engaged in the processes of interpretation and analysis of the results.

Partial least squares path modeling (PLS-PM) has begun to achieve a widespread practical usage [4-7] if there is a need to make a model of the social contribution of enterprises to the development of the territories or regions. In this study a set of indicators to assess the strategy of sustainable development of the enterprise and further modeling was formed using the resulting and attributive approaches. This means that it can be used to analyze any complex systems that depend on available statistics.

Maintaining the sustainability is possible through a combination of traditional econometric approaches, taking into account the prerequisites and specifics of operating activities on different levels (including the regional one) [2]. So it should be noted that latent variables are considered to be general qualitative indicators, while explicit variables are statistics ones. The model of the description of the target variable consists of quantitative indicators and implicit variables.

Considering the features of building a regression model using the least squares method it should be noted that this mathematical method helps to minimize the sum of the squares of the deviations of some functions from the variables that are searched [10]. This method can be represented as a set of four successive stages: 1) collection of statistical data; 2) determination of correlation coefficients between variables; 3 ) estimation of regression parameters; general estimation of the model relevance.

The PLS-PM method differs from covariance-based modeling (variability of random variables) since it is not about the constructing a general model of factors for data. On the contrary this method corresponds to composite (consolidated) modeling [8]. This means that it can be used to analyze large data sets to assess the performance of the latent variables.

It is worth noting that there is no need for statistical distribution of variables and random deviations while using the method of projection on latent structures for modeling.

The modeling is performed according to the following algorithm: hypotheses about the existence of latent variables and the relationship between them are put forward, whereupon their indicators are determined and numerical modeling and evaluation of the model quality is performed, followed by interpretation of the obtained results.

\footnotetext{
* Corresponding author: yaroslavayakovenko@gmail.com
} 
The task for modeling using the PLS-PM method has the form of a data matrix $Z$ of the dimension $Z_{n} \times Z_{i}$ :

$$
\mathrm{Z}=\begin{array}{cccc}
Z_{11} & Z_{12} & \cdots & Z_{1 i} \\
& Z_{22} & \cdots & Z_{2 i} \\
& & \ddots & \vdots \\
& & & Z_{n i}
\end{array}
$$

where $n$-the number of modeling objects, $a_{i}-$ the number of features.

Although the formal development of the composite models $[4,8]$ and the projection on the latent structure using PLS-PM/PCA-PM methods [1,7] have been studied previously, the use of an adapted composite model for modeling complex economic systems (in our case mining enterprises) was not considered.

Each data array $\mathrm{Z}$ can be divided into blocks. If to take the fact that each artifact is modeled as a composite as a basis - then it is determined by a unique block of $\mathrm{Z}_{\mathrm{ni}}-$ indicators.

Table 1. Variable PLS-PM models of sustainable development.

\begin{tabular}{|c|c|c|}
\hline $\begin{array}{c}\text { Latent } \\
\text { variable }\end{array}$ & Explicit variable & $\begin{array}{l}\text { Designation / } \\
\text { unit of } \\
\text { measurement }\end{array}$ \\
\hline \multirow[b]{2}{*}{$\begin{array}{l}\text { Sustainable } \\
\text { development }\end{array}$} & $\begin{array}{l}\text { Number of jobs in the } \\
\text { industry }\end{array}$ & $\mathrm{k} 1 \mathrm{sd} /$ thsd \\
\hline & $\begin{array}{l}\text { The structure of gross value } \\
\text { added in the gross domestic } \\
\text { product }\end{array}$ & $\mathrm{k}_{2 \mathrm{sd}} / \%$ \\
\hline \multirow{6}{*}{ Economy } & Profitability of activity & $\mathrm{k}_{1 \text { econ }} / \%$ \\
\hline & Return on investment & $\mathrm{k}_{2 \text { econ} / \text { units }}$ \\
\hline & $\begin{array}{l}\text { Equity maneuverability } \\
\text { ratio }\end{array}$ & $\mathrm{k}_{3 \text { econ }} /$ units \\
\hline & $\begin{array}{l}\text { The ratio of capital } \\
\text { investment to gross output }\end{array}$ & $\mathrm{k}_{4} \mathrm{econ} / \%$ \\
\hline & \begin{tabular}{|l|} 
Labor productivity in value \\
terms
\end{tabular} & $\mathrm{k}_{5}$ econ/ thsd UAH \\
\hline & $\begin{array}{l}\text { Costs for modernization } \\
\text { and implementation of } \\
\text { innovations }\end{array}$ & $\mathrm{k}_{6 \mathrm{econ}} /(\mathrm{yes} / \mathrm{no})$ \\
\hline \multirow{3}{*}{ Society } & $\begin{array}{l}\text { Remuneration with } \\
\text { deduction for social } \\
\text { insurance }\end{array}$ & k1soc/ \% \\
\hline & \begin{tabular}{|l|} 
Pension liabilities \\
\end{tabular} & $\mathrm{k}_{2 \mathrm{soc}} /$ thsd UAH \\
\hline & $\begin{array}{l}\text { Deductions for social } \\
\text { events }\end{array}$ & k3sod/ thsd UAH \\
\hline \multirow{4}{*}{ Ecology } & $\begin{array}{l}\text { Revenues to the state from } \\
\text { emissions of pollutants into } \\
\text { the atmosphere }\end{array}$ & $\mathrm{k}_{\text {lecol }} /$ thsd UAH \\
\hline & \begin{tabular}{|l|}
$\begin{array}{l}\text { Use of fuel and energy } \\
\text { resources }\end{array}$ \\
\end{tabular} & $\mathrm{k}_{2 \mathrm{ecol}} / \%$ \\
\hline & $\begin{array}{l}\begin{array}{l}\text { Rent for special use of } \\
\text { water }\end{array} \\
\end{array}$ & $\mathrm{k}_{3 \mathrm{ecol}} /$ thsd UAH \\
\hline & $\begin{array}{l}\text { Initiatives to reduce the } \\
\text { impact of production on the } \\
\text { environment }\end{array}$ & $\mathrm{k}_{4 \mathrm{ecol}} /(\mathrm{yes} / \mathrm{no})$ \\
\hline \multirow{3}{*}{$\begin{array}{l}\text { Integrative } \\
\text { dimension }\end{array}$} & $\begin{array}{l}\text { Coefficient of stability of } \\
\text { economic growth }\end{array}$ & $\mathrm{k}_{1 \text { int }} / \%$ \\
\hline & $\begin{array}{l}\begin{array}{l}\text { Payments in favor of the } \\
\text { state }\end{array} \\
\end{array}$ & $\mathrm{k}_{2 \text { int }} /$ thsd UAH \\
\hline & $\begin{array}{l}\text { The relative share of the } \\
\text { enterprise in the market of } \\
\text { iron products (industry } \\
\text { market) }\end{array}$ & $\mathrm{k}_{3 \text { int }} /$ share units \\
\hline
\end{tabular}

Sustainable development of a mining enterprise should be considered on the basis of an integrated approach as an integration of all of the components (economic, environmental, social, integrative). In this study four latent variables associated with explicit (quantitative) variables are used (see Table 1): the level of the sustainable enterprise development (Sustainable Development); the level of economic development (Economy); the level of social development (Society); the level of ecological development (Ecology); the level of integrative development (Integrative dimension).

At the same time the intra-block covariance matrix $Z_{n i}$ is not limited (latent variables are related to each other), which allows the indicators of one block to effectively perform covariance.

In contrast to the intra-block covariance matrix, the inter-block covariance matrix is limited because the composites (latent variables) carry information between the respective blocks.

\section{Method}

A feature of analytical research of such a multifaceted phenomenon as sustainability of development is the use of both quantitative and qualitative indicators. Therefore, the indicators for comparison were separated according to this principle. The dynamic (time) series are represented by a set of statistical indicators in a chronological order.

Step by step one can assess the level of sustainable development of enterprises on the example of the Ukrainian mining enterprises (Metinvest Group (Ingulets, Central and Northern GOK), Arcelor Mittal (AM Kryvyi Rih), Ferrexpo AG (Poltava GOK) and DCH Group (Evraz Sukha Balka) taking into account the period for the last 5 years starting from 2014. Since the value of explicit variables of the largest GOK for five years is taken into account, the representativeness of the sample is confirmed by sufficient volume and quota (a certain number of variables in each direction) [9].

It is assumed that each block $\mathrm{Z}_{\mathrm{i}}$ is associated with a latent (implicit) variable $\mathrm{LV}_{\mathrm{i}}$. Taking into account that latent variables are abstract, the internal model of relationships between variables can be presented analytically:

$$
\mathrm{LV}_{\text {sd }}=\alpha_{0}+\alpha_{1} \mathrm{LV}_{\text {econ }}+\alpha_{2} \mathrm{LV}_{\text {soc }}+\alpha_{3} \mathrm{LV}_{\text {ecol }}+\alpha_{4} \mathrm{LV}_{\text {int }}+\beta_{\text {sd }},(2)
$$

where $\mathrm{LV}_{\mathrm{sd}}$ - a latent variable of sustainable development; $\alpha_{0}$ - a free member; $\alpha_{1} \ldots \alpha_{3}$ - path coefficients to indicate the strength and direction of communication between latent variables; $\mathrm{LV}_{\text {econ }}$ - a latent variable of the economy; $\mathrm{LV}_{\mathrm{soc}}-$ a latent variable of society; $L_{\text {ecol }}$ - a latent variable of ecology; $\mathrm{LV}_{\text {int }}$ - a latent variable of integrative dimension; $\beta_{\mathrm{sd}}-\mathrm{a}$ residual member.

The internal model must meet a number of requirements, in particular: the system of linear equations is characterized by recursiveness; random deviations are allowed; the model itself is regressive.

The initial model is shown in Fig. 1 (latent variables are represented by colored rectangles, and explicit variables are not). 
Analyzing the sustainable development of mining enterprises on the basis of reporting data, one can identify a number of indicators that characterize the components of the sustainable development (these are explicit variables from Fig.1, the source of which were the official financial and non-financial published reports of the mentioned enterprises (Metinvest Group (Ingulets, Central and Northern GOK), Arcelor Mittal (AM Kryvyi Rih), Ferrexpo AG (Poltava GOK) and DCH Group (Evraz Sukha Balka) for the period of 2014-2018).

The relationship of latent variables is an internal model while the relationship between latent and explicit variables is an external model.

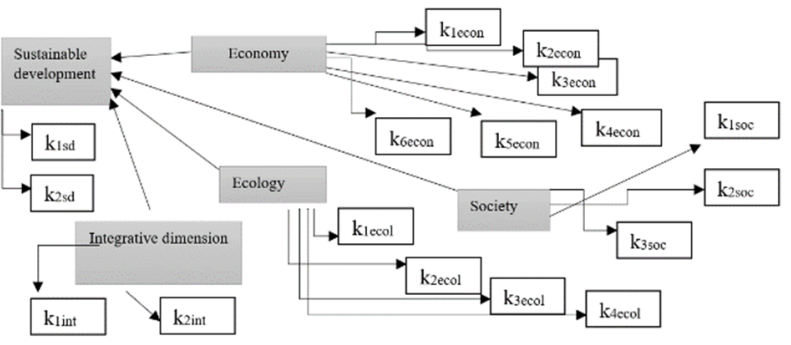

Fig. 1. The initial model of sustainable development.

The external model characterizes the relationship between explicit and latent variables. There are two types of external models by types of connections - reflective (preference is given to latent variables) and formative (latent variables arose due to explicit) one.

In the method of modeling path coefficients using the Partial Least Squares method, the concept of estimating the latent variable (linear combination of the corresponding explicit variables) arises.

Since each latent variable is directly related to two or three explicit variables, the external model of the reflective type in this case can be presented in a form of a system of equations:

$$
\begin{aligned}
& \int \mathrm{Z}_{\mathrm{k} 1 \mathrm{sd}}=\alpha_{0 \mathrm{k} 1 \mathrm{sd}}+\alpha_{1 \mathrm{k} 1 \mathrm{sd}} \mathrm{LV}_{\mathrm{sd}}+\beta_{\mathrm{k} 1 \mathrm{sd}} \\
& \mathrm{Z}_{\mathrm{k} 2 \mathrm{sd}}=\alpha_{0 \mathrm{k} 2 \mathrm{sd}}+\alpha_{1 \mathrm{k} 2 \mathrm{sd}} \mathrm{LV}_{\mathrm{sd}}+\beta_{\mathrm{k} 2 \mathrm{sd}} \\
& \mathrm{Z}_{\mathrm{k} 1 \mathrm{econ}}=\alpha_{0 \mathrm{k} 1 \mathrm{econ}}+\alpha_{1 \mathrm{k} 1 \mathrm{econ}} \mathrm{LV}_{\mathrm{econ}}+\beta_{\mathrm{k} 1 \mathrm{econ}} \\
& \mathrm{Z}_{\mathrm{k} 2 \mathrm{econ}}=\alpha_{0 \mathrm{k} 2 \mathrm{econ}}+\alpha_{1 \mathrm{k} 2 \mathrm{econ}} \mathrm{LV}_{\mathrm{econ}}+\beta_{\mathrm{k} 2 \mathrm{econ}} \\
& \mathrm{Z}_{\mathrm{k} 1 \mathrm{soc}}=\alpha_{0 \mathrm{k} 1 \mathrm{soc}}+\ldots_{1 \mathrm{k} 1 \mathrm{soc}} \mathrm{LV}_{\mathrm{soc}}+\beta_{\mathrm{k} 1 \mathrm{soc}} \\
& \mathrm{Z}_{\mathrm{k} 2 \mathrm{soc}}=\alpha_{0 \mathrm{k} 2 \mathrm{soc}}+\alpha_{1 \mathrm{k} 2 \mathrm{soc}} \mathrm{LV}_{\mathrm{soc}}+\beta_{\mathrm{k} 2 \mathrm{soc}} \\
& \mathrm{Z}_{\mathrm{k} 1 \mathrm{ecol}}=\alpha_{0 \mathrm{k} 1 \mathrm{ecol}}+\alpha_{1 \mathrm{k} 1 \mathrm{ecol}} \mathrm{LV}_{\mathrm{ecol}}+\beta_{\mathrm{k} 1 \mathrm{ecol}} \\
& \mathrm{Z}_{\mathrm{k} 2 \mathrm{ecol}}=\alpha_{0 \mathrm{k} 2 \mathrm{ecol}}+\alpha_{1 \mathrm{k} 2 \mathrm{ecol}} \mathrm{LV}_{\mathrm{ecol}}+\beta_{\mathrm{k} 2 \mathrm{ecol}} \\
& \mathrm{Z}_{\mathrm{k} 1 \mathrm{int}}=\alpha_{0 \mathrm{k} 1 \mathrm{int}}+{ }^{\cdots}{ }_{1 \mathrm{kint}} \mathrm{LV} V_{\mathrm{int}}+\beta_{\mathrm{k} 1 \mathrm{int}} \\
& \mathrm{Z}_{\mathrm{k} 2 \text { int }}=\alpha_{0 \mathrm{k} 2 \text { int }}+\alpha_{1 \mathrm{k} 2 \text { int }}+\beta_{\mathrm{k} 2 \text { int }}
\end{aligned}
$$

where $Z_{\mathrm{k} 1 \mathrm{sd}} \ldots Z_{\mathrm{k} 2 \text { int }}-$ explicit variables; $\alpha_{0 \mathrm{k} 1 \mathrm{sd}} \ldots \alpha_{0 \mathrm{k} 2 \text { int }}-$ free members; $\alpha_{1 \mathrm{k} 1 \mathrm{sd}} \ldots \alpha_{1 \mathrm{k} 2 \mathrm{int}}-$ load factors; $\beta_{\mathrm{k} 1 \mathrm{sd}} \ldots \beta_{\mathrm{k} 2 \mathrm{int}}-$ residual members.

Latent variables are not directly measured, so in order to denote their evaluation $\mathrm{Y}_{\mathrm{i}}$ is used:

$$
\mathrm{Y}_{\mathrm{i}}=\widehat{\mathrm{LV}}_{\mathrm{i}}=\sum_{\mathrm{n}}^{\mathrm{i}} \gamma_{\mathrm{in}} \mathrm{Z}_{\mathrm{in}},
$$

$$
\begin{aligned}
& \mathrm{LV}_{\mathrm{sd}}=\mathrm{Y}_{\mathrm{sd}}=\delta_{\mathrm{k} 1 s \mathrm{~d}} \mathrm{Z}_{\mathrm{k} 1 \mathrm{sd}}+\delta_{\mathrm{k} 2 \mathrm{sd}} \mathrm{Z}_{\mathrm{k} 2 \mathrm{sd}} \\
& \mathrm{LV}_{\text {econ }}=\mathrm{Y}_{\text {econ }}=\delta_{\mathrm{k} 1 \text { econ }} Z_{\mathrm{k} 1 \text { econ }}+\delta_{\mathrm{k} 2 \text { econ }} Z_{\mathrm{k} 2 \text { econ }}+\delta_{\mathrm{k} 3 \text { econ }} Z_{\mathrm{k} 3 \text { econ }}+ \\
& +\delta_{\mathrm{k} 4 \mathrm{econ}} Z_{\mathrm{k} 4 \text { econ }}+\delta_{\mathrm{k} 5 \text { econ }} Z_{\mathrm{k} 5 \text { econ }}+\delta_{\mathrm{k} 6 \mathrm{econ}} \mathrm{Z}_{\mathrm{k} 6 \mathrm{econ}} \\
& \mathrm{LV}_{\mathrm{soc}}=\mathrm{Y}_{\mathrm{soc}}=\delta_{\mathrm{k} 1 \mathrm{soc}} \mathrm{Z}_{\mathrm{k} 1 \mathrm{soc}}+\delta_{\mathrm{k} 2 \mathrm{soc}} Z_{\mathrm{k} 2 \mathrm{soc}}+\delta_{\mathrm{k} 3 \mathrm{soc}} \mathrm{Z}_{\mathrm{k} 3 \mathrm{soc}} \\
& \mathrm{LV}_{\text {ecol }}=\mathrm{Y}_{\text {ecol }}=\delta_{\mathrm{k} 1 \text { ecol }} \mathrm{Z}_{\mathrm{k} 1 \text { ecol }}+\delta_{\mathrm{k} 2 \text { ecol }} \mathrm{Z}_{\mathrm{k} 2 \text { ecol }}+\delta_{\mathrm{k} 3 \mathrm{ecol}} \mathrm{Z}_{\mathrm{k} 3 \mathrm{ecol}}+ \\
& +\delta_{\mathrm{k} 4 \mathrm{ecol}} \mathrm{Z}_{\mathrm{k} 4 \mathrm{ecol}} \\
& L V_{\text {int }}=Y_{\text {int }}=\delta_{\text {k1int }} Z_{\mathrm{k} 1 \text { int }}+\delta_{\text {k2int }} Z_{\mathrm{k} 2 \text { int }}+\delta_{\mathrm{k} 3 \text { int }} Z_{\mathrm{k} 3 \text { int }}
\end{aligned}
$$

where $\delta_{\mathrm{k} 1 \mathrm{sd}} \ldots \delta_{\mathrm{k} 3 \mathrm{int}}-$ external scales of the model.

Therefore we can distinguish the main stages of calculation in the process of PLS-PM-modeling, in particular: external scales of the model to obtain estimates of latent variables, path coefficients of the internal model and correlation coefficients between latent and explicit variables.

The first stage of PLS-PM modeling is an iterative process. Therefore to obtain the values of the estimates of the latent variables $\mathrm{Y}_{\mathrm{i}}$, the initial values of the external weights $\delta_{\mathrm{k} 1 \mathrm{sd}} \ldots \delta_{\mathrm{k} 3 \text { int }}$ are set.

It should be noted that this stage is a key one, because the calculation of the values of external weights allows the evaluation of latent variables. After this stage the system of linear equations can be solved using the PLS method and the correlation coefficients can be calculated.

Taking into account the weights (to the required degree of convergence of external weights) the results of recalculation of values of estimates of latent variables using internal rather than external model (one calculate the values of estimates of latent variables as linear combinations of estimates of other latent rather than explicit variables) can be described like:

$$
\mathrm{V}_{\mathrm{i}}=\sum_{\mathrm{n}<->\mathrm{j}} \mathrm{e}_{\mathrm{nj}} \mathrm{Y}_{\mathrm{n}},
$$

where $\mathrm{V}_{\mathrm{i}}$ - the sum of the estimates of those latent variables, which are related to n-latent variable; $\mathrm{e}_{\mathrm{nj}}-$ internal scales of the model.

Accordingly, the recalculation of the values of external weights for the external model of the reflective type can be described according to the formula:

$$
\delta_{j \mathrm{n}}=\left(Y_{j}^{\prime} Y_{j}\right)^{-1} Y_{j}^{\prime} \mathrm{Z}_{j \mathrm{n}}
$$

It is important to note that with each new step of the iterative process the degree of convergence (convergence) of external weights also changes.

Similarly, the calculation of the path coefficients of the internal model can be described according to the formula:

$$
\alpha_{j_{\mathrm{n}}}=\left(Y_{\mathrm{n}}{ }^{\prime} Y_{\mathrm{n}}\right)^{-1} Y_{\mathrm{n}}{ }^{\prime} Y_{j}
$$

Regarding the calculation of load factors they are equated to the correlation coefficients between latent and explicit variables.

Modeling by the method of PLS-PM and the necessary calculations were implemented in the software environment SmartPLS 3.0, using which one can present the visualization of the coefficients of external loads of the external model.

The authors do not take into account the variables of the PLS-PM models of sustainable development $\mathrm{k}_{6 \text { econ }}$ (the costs of modernization and innovation) and $\mathrm{k}_{4 \mathrm{ecol}}$ (the initiatives to reduce the impact of production on the environment) which have constant binary values. 
Analysis of the model of sustainable development by the PLS-PM method involves the sequential implementation of the following steps: 1) verification of the blocks for internal consistency; 2) assessment of the significance of external variables; 3 ) detection of crosscorrelations of variable blocks with latent variables of other blocks; 4) studying of the consistency of the internal model; 5) checking the quality of the model; 6) further optimization.

The first stage (verification of blocks for internal consistency) in the framework of PLS-PM modeling can be done by using several criteria, in particular: Cronbach's alpha coefficient, a structural reliability and an average variance extracted (AVE).

The acceptable value of the AVE indicator is in the range starting from 0.50 and above because the constructed model explains more than half of the variance of the indicator values in this case. The blocks "Ecology" and "Sustainable Development" meet this criterion.

It is shown in the Table 2 that the blocks "Economy", "Ecology" and "Sustainable Development" have high values of Cronbach's alpha coefficients and blocks "Society" and "Integrative Dimension" are characterized by low internal consistency.

Table 2. Checking internal consistency in blocks.

\begin{tabular}{|l|c|c|c|}
\hline \multicolumn{1}{|c|}{ Block } & $\begin{array}{c}\text { Cronbach's } \\
\text { alpha } \\
\text { coefficient }\end{array}$ & $\begin{array}{c}\text { Composite } \\
\text { reliability } \\
\text { (CR) }\end{array}$ & $\begin{array}{c}\text { Average } \\
\text { variance } \\
\text { extracted } \\
\text { (AVE) }\end{array}$ \\
\hline Economy & 0,277 & 0,472 & 0,269 \\
\hline Society & $-0,370$ & 0,468 & 0,301 \\
\hline Ecology & 0,755 & & 0,493 \\
\hline $\begin{array}{l}\text { Integrative } \\
\text { dimension }\end{array}$ & $-0,363$ & 0,315 & 0,332 \\
\hline $\begin{array}{l}\text { Sustainable } \\
\text { development }\end{array}$ & 0,875 & 0,014 & 0,824 \\
\hline
\end{tabular}

As for the Cronbach's alpha coefficient - it characterizes the reliability and internal consistency of the model based on the existing relationships between the observed variables.

The calculation is performed on the basis of ranking the indicators according to the level of reliability provided by the algorithm of the PLS-PM method. If its value is greater than 0.5 , it indicates confirmation of the assumption of equal reliability of all indicators.

All observed variables show the existence of a load on the corresponding component, which confirms the convergent validity. The variables of the block "Sustainable development" are characterized by the greatest reliability.

At the same time the Cronbach's alpha coefficient in the case of an increase in the number of objects of observation may slightly contribute to the underestimation of the internal consistency in the calculations.

Therefore, to assess the degree of compliance of indicators with latent variables the composite reliability indicator is used with the help of which it is possible to trace the degree of compliance of indicators included in the model with latent variables [11].
In this case, some indicators of the model have a fairly high value (for example, for the economy -0.472 , for the society -0.468$)$, which suggests the presence of high structural consistency.

It is also important to determine the validity of the model, i.e. the degree to which the indicators correspond to the planned characteristics, namely the numerical expression of aspects of sustainable development.

\section{Results and discussion}

In order to ensure that the model characterizes the phenomena not covered by other components, one can use not only the average extracted variance. The FornellLarker test [5] and the heterotrait-monotrait ratio are the other estimates, which are also based on a step transition. Since latent variable models do not contain conceptually similar constructs, one can use both.

The Fornell-Larker calculation criterion is shown in Table 3. As we can see, the square of correlations between each pair of components of the model of sustainable development is less than the average extracted variance, so this meets the requirements of the criterion.

Table 3 The Fornell-Larker criterion.

\begin{tabular}{|c|c|c|c|c|c|}
\hline & $\begin{array}{l}30 \\
\frac{80}{8} \\
\frac{8}{9}\end{array}$ & 己 & 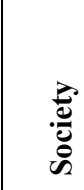 & 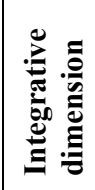 & 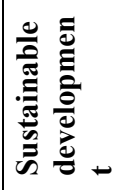 \\
\hline Ecology & 0.702 & - & - & |- & - \\
\hline Economy & 0.324 & 0.518 & - & - & - \\
\hline Society & 0.384 & 0.362 & 0.549 & - & - \\
\hline $\begin{array}{l}\text { Integrative } \\
\text { dimension }\end{array}$ & 0.440 & 0.007 & 0.406 & 0.576 & - \\
\hline $\begin{array}{l}\text { Sustainable } \\
\text { development }\end{array}$ & 0.606 & 0.598 & 0.549 & 0.524 & 0.908 \\
\hline
\end{tabular}

Estimates by the criterion of hetero- and monocharacteristics, shown in Fig. 2, indicate the presence of discriminant validity of blocks (when the value of the criterion is less than 0.90 ). It follows that the used reflective evaluation construct is discriminant-valid.

As for the course of further hypotheses - the impact of four latent variables on sustainable development will be used. The adequacy of the constructed model with the actual data for the period from 2014 to 2018 will be established by Fisher's criterion, which evaluates the statistical significance of the determination index $R_{2}$. In this case the estimate is 0.0014 , which is less than the specified level of significance (0.05). This means that factors significantly affect the provision of sustainable development.

The verification of internal consistency also occurs by determining the eigenvalues of the correlation matrix of explicit variables (Table 4).

All blocks have a positive correlation with the latent variable, which indicates the internal consistency in the blocks. Once we have obtained the consistency indicators of the model, we can present the schemes of correlations. 


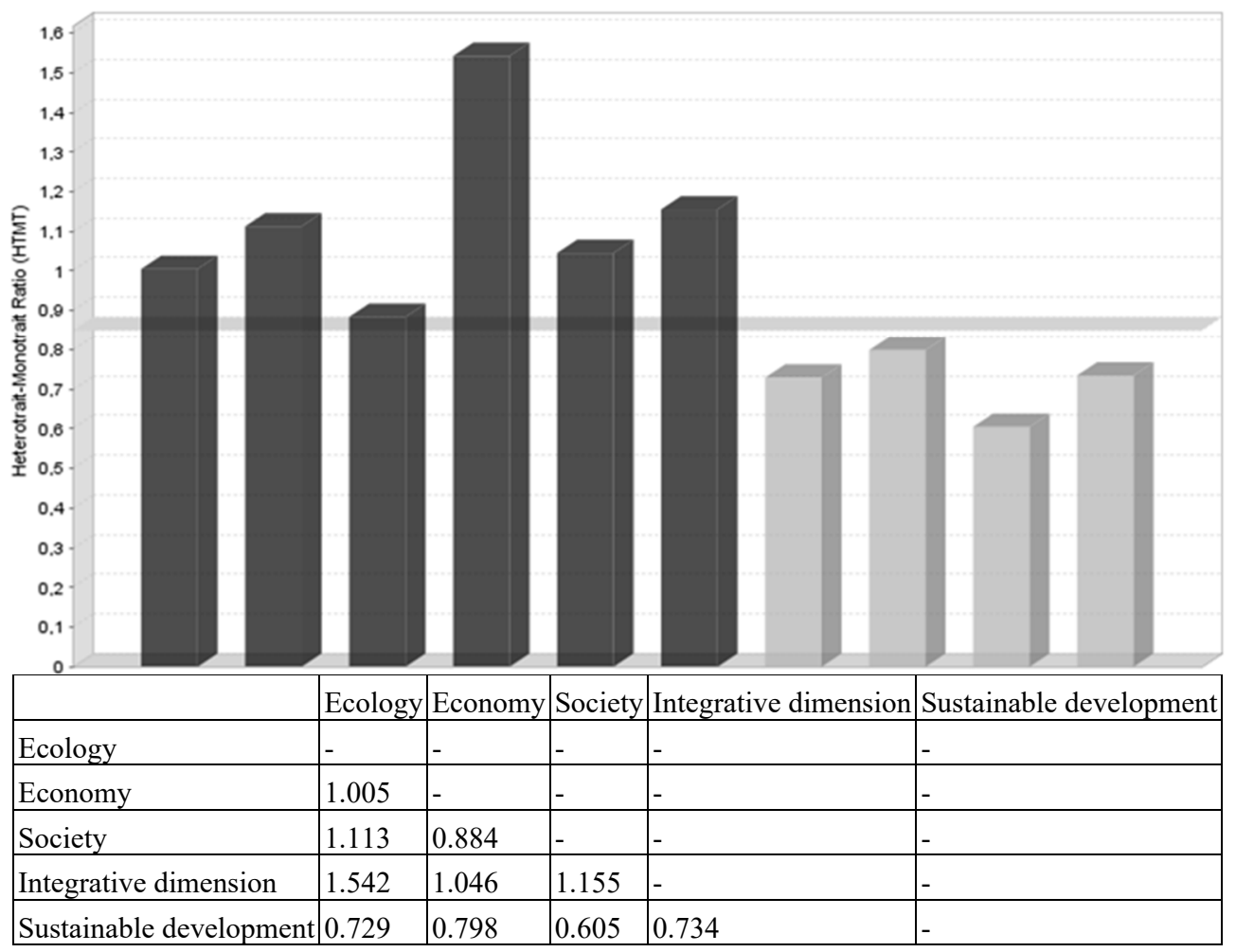

Fig. 2. Criterion of hetero- and monocharacteristics.

Table 4. Correlation of latent variables.

\begin{tabular}{|l|c|c|c|c|c|}
\hline $\begin{array}{c}\text { Latent variab- } \\
\text { les }\end{array}$ & $\begin{array}{c}\text { Eco- } \\
\text { logy }\end{array}$ & $\begin{array}{c}\text { Eco- } \\
\text { nomy }\end{array}$ & $\begin{array}{c}\text { So- } \\
\text { ciety }\end{array}$ & $\begin{array}{c}\text { Integra- } \\
\text { tive di- } \\
\text { mension }\end{array}$ & $\begin{array}{c}\text { Sustainable } \\
\text { development }\end{array}$ \\
\hline Ecology & - & 0.324 & 0.384 & 0.440 & 0.606 \\
\hline Economy & 0.324 & - & 0.362 & 0.007 & 0.598 \\
\hline Society & 0.384 & 0.362 & - & 0.406 & 0.549 \\
\hline $\begin{array}{l}\text { Integrative } \\
\text { dimension }\end{array}$ & 0.440 & 0.007 & 0.406 & - & 0.524 \\
\hline $\begin{array}{l}\text { Sustainable } \\
\text { development }\end{array}$ & 0.606 & 0.598 & 0.549 & 0.524 & - \\
\hline
\end{tabular}

Table 5. The values of the coefficients of the external model.

\begin{tabular}{|c|c|c|c|}
\hline Block & Variable & \begin{tabular}{|l} 
External \\
scales
\end{tabular} & $\begin{array}{l}\text { External } \\
\text { loads }\end{array}$ \\
\hline \multirow{2}{*}{\begin{tabular}{|l|}
$\begin{array}{l}\text { Sustainable } \\
\text { development }\end{array}$ \\
\end{tabular}} & $\mathrm{k}_{1 s d}$ & -0.445 & -0.872 \\
\hline & $\mathrm{k}_{2 \mathrm{sd}}$ & 0.650 & 0.942 \\
\hline \multirow{5}{*}{ Economy } & $\mathrm{k}_{1 \mathrm{econ}}$ & 0.493 & 0.560 \\
\hline & $\mathrm{k}_{2 \text { econ }}$ & -0.277 & -0.284 \\
\hline & $\mathrm{k}_{3 \mathrm{econ}}$ & 0.341 & 0.702 \\
\hline & $\mathrm{k}_{4 \mathrm{econ}}$ & 0.222 & 0.180 \\
\hline & k5econ & 0.563 & 0.651 \\
\hline \multirow{3}{*}{ Society } & $\mathrm{k}_{\text {1soc }}$ & 0.530 & 0.448 \\
\hline & $\mathrm{k}_{2 \mathrm{soc}}$ & 0.923 & 0.835 \\
\hline & $\mathrm{k}_{3 \mathrm{soc}}$ & -0.102 & 0.075 \\
\hline \multirow{3}{*}{ Ecology } & $\mathrm{k}_{\text {lecol }}$ & 0.714 & 0.923 \\
\hline & $\mathrm{k}_{2 \mathrm{ecol}}$ & 0.006 & 0.150 \\
\hline & $\mathrm{k}_{3 \mathrm{ecol}}$ & 0.437 & 0.778 \\
\hline \multirow{3}{*}{ Integrative dimension } & $\mathrm{k}_{\text {1int }}$ & -0.281 & -0.191 \\
\hline & $\mathrm{k}_{\text {2int }}$ & 0.000 & 0.192 \\
\hline & $\mathrm{k}_{3 \text { int }}$ & 0.986 & 0.960 \\
\hline
\end{tabular}

The second stage is the assessment of the significance of external variables, which is possible using the software capabilities of the SmartPLS 3.0 package. In particular, the external model was tested (Table 5).

Shown in Fig. 3 correlation coefficients of explicit variables and latent variables (by blocks) indicate the following: low correlation (close to or equal to zero) is observed for one variable in the blocks "Integrative Dimension" and "Ecology", which leads to internal inconsistency.

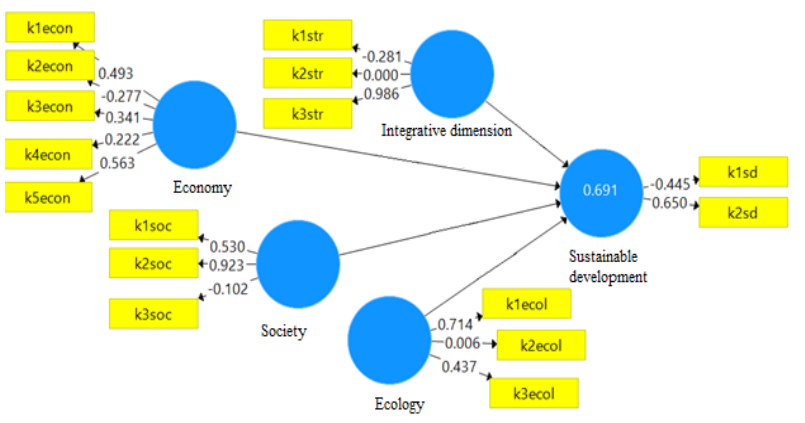

Fig. 3. External scales of the model.

To assess the significance of the obtained values of external weights and their relevance by the method of bias correction (BC), one can obtain additional information for the analysis of the reliability of the results (Table 6).

Since the given values of the coefficients differ from zero, there is a significant strength of the links of exogenous structures with endogenous.

The third stage is the verification of cross-correlations. Such verification is necessary to trace the relationships of explicit variables with latent ones within the respective blocks and, if necessary, to exclude those indicators whose connection with the latent variables of other blocks 
is higher in comparison with a similar variable of the corresponding block. In this case, no significant deviations in loyalty to the variables of certain blocks were detected (except for isolated cases with $\mathrm{k}_{1 \mathrm{sd}}, \mathrm{k}_{2 \mathrm{econ}}$, $\mathrm{k}_{2 \mathrm{ecol}}, \mathrm{k}_{\text {lint }}$ and $\mathrm{k}_{2 \text { int }}$ ) which indicates the admissibility of their consideration. The presence of deviations is explained by the fact that the method of "convenient sampling" was used, which serves as a limitation due to the objective difficulties of data collection. It means that the presented results are an analytical (not a statistical) generalization.

Table 6. Offset of confidence intervals.

\begin{tabular}{|l|c|c|c|c|}
\hline \multicolumn{1}{|c|}{ Trajectories } & \multirow{2}{*}{$\begin{array}{c}\text { Initial } \\
\text { sample }\end{array}$} & $\begin{array}{c}\text { The average } \\
\text { value for the } \\
\text { sample }\end{array}$ & \multicolumn{2}{|c|}{ Offset } \\
\cline { 4 - 6 } & & $\mathbf{2 . 5 \%}$ & $\mathbf{9 7 . 5 \%}$ \\
\hline $\begin{array}{l}\text { Ecology } \\
\text { Sustainable } \\
\text { development }\end{array}$ & 0.245 & 0.217 & -0.187 & 0.523 \\
\hline $\begin{array}{l}\text { Economy } \rightarrow \\
\text { Sustainable } \\
\text { development }\end{array}$ & 0.464 & 0.004 & -0.650 & 0.637 \\
\hline $\begin{array}{l}\text { Society } \\
\text { Sustainable } \\
\text { development }\end{array}$ & 0.143 & 0.084 & -0.322 & 0.413 \\
$\begin{array}{l}\text { Integrative dimension } \\
\text { S Sustainable } \\
\text { development }\end{array}$ & 0.355 & 0.342 & -0.089 & 0.716 \\
\hline
\end{tabular}

The presence of lateral collinearity (when the model is estimated by several interrelated high-probability variables) can be traced if we pay attention to the maximum within the sample values of the variance inflation factor (VIF) [3]. In this case, the value of this indicator for the blocks "Ecology" and "Society" are 1.445 and 1.439 and the internal values of each indicator of the block are less than the threshold $(<5 \%)$.

In the fourth and fifth stages, we will consider the internal model of sustainable development, check it on the index of compliance and obtain estimates of latent variables in the form of a system of equations.

Since the "path" coefficients and values of $\mathrm{R}^{2}$ for endogenous latent variables (in this case $\mathrm{R}^{2}=0.691$ ) are significant, that indicates a close relationship between the performance trait and the studied factors, ie the model explains approximately $69 \%$ of the variance of this indicator, and only $31 \%$ explain other factors. It is also assumed that the latent variable determines the variance of each indicator by at least $50 \%$.

Checking the quality of the model involves the following procedures: calculation of the coefficients d_ULS (square Euclidean distance) and d_G (geodetic distance) [4]. Both coefficients characterize the quality of internal and external models of the system and serve as an indicator of the predictive reliability of the model. The $\mathrm{d}$ G criterion is based on the calculations of the eigenvalues of the PLS model. A model is considered to be qualitative when the difference between the correlation matrix resulting from the model and the empirical correlation matrix is so small that it can be attributed to the sampling error. If this difference is insignificant (criteria d_ULS and d_G are higher than 0.05), then the model is qualitative. In our case both criteria are much higher than the minimum allowable values (d_ULS = 4.409 ; d_G $=2.749$ ), which indicates the prognostic reliability of the model.

The sixth stage is the further optimization. The PLSPM simulation method is used for multidimensional data analysis (however there is no data distribution) which can cause standard errors. Therefore structural modeling of results is performed additionally on the basis of a nonparametric statistical method, which does not require a normalized data distribution. This means that a bootstrap is used to check the significance of the coefficients. At this stage the estimates of path coefficients are analyzed as well as the results of checking the criterion of T-statistics (the ratio of the original sample to the standard deviation).

The values of the cumulative effect of the coefficients of the trajectories (Table 7), indicate the validity of the selected trajectories. According to the generally accepted approaches, the limit values of $\mathrm{P}$ (significance) are considered to be the following: for the value of T-statistics over $1.65-10 \%$, over $1.96-5 \%$. It is a consequence of the statistical probability of error in cases where the empirical value of significance exceeds the norm.

Table 7. The values of the cumulative effect of the coefficients of the trajectories.

\begin{tabular}{|l|c|c|c|c|c|}
\hline Trajectories & $\begin{array}{l}\text { Original } \\
\text { sample }\end{array}$ & $\begin{array}{c}\text { The } \\
\text { average } \\
\text { value for } \\
\text { the } \\
\text { sample }\end{array}$ & STDEV & $\begin{array}{c}\text { T- } \\
\text { statistics }\end{array}$ & P \\
\hline $\begin{array}{l}\text { Ecology } \\
\text { Sustainable } \\
\text { development }\end{array}$ & 0.245 & 0.217 & 0.185 & 1.327 & 0.185 \\
\hline $\begin{array}{l}\text { Economy } \rightarrow \\
\text { Sustainable } \\
\text { development }\end{array}$ & 0.464 & 0.004 & 0.452 & 1.027 & 0.305 \\
\hline $\begin{array}{l}\text { Society } \\
\text { Sustainable } \\
\text { development }\end{array}$ & 0.143 & 0.084 & 0.189 & 0.760 & 0.448 \\
\hline $\begin{array}{l}\text { Integrative } \\
\text { dimension } \\
\text { Sustainable } \\
\text { development }\end{array}$ & 0.355 & 0.342 & 0.193 & 1.842 & 0.066 \\
\hline
\end{tabular}

By estimating the magnitude of the effect $\mathrm{f}^{2}$, it is possible to investigate the relevance of the components to substantiate exogenous influencing factors. Such an analysis is possible by excluding a certain component of the model to assess the impact of the removed element on the stability of the structure. It is assumed that the value of $\mathrm{f}^{2}$ at a level above 0.02 means the presence of a significant effect of the latent variable. In our model the value of $\mathrm{f}^{2}$ in all cases exceeds 0.02 (the magnitude of the effect of the components "Economy", "Society", "Ecology" and "Integrative dimension" for the endogenous latent variable "Sustainable Development" are $0.539,0.046,0.134$ and 0.281 ). This shows that all of the components have a significant impact on the sustainable development.

As for the interpretation of the obtained results, the performed modeling revealed the following feature: in the 
absence of stable trends in the object of modeling (mining enterprises) changes in trends will not be recognized in case of a sharp change in development conditions. Thus, the chosen approach to building a multidimensional model that reflects the most significant and stable internal and external relationships was correct. At the same time, the assessment and analysis of the strategy of sustainable development of the enterprise in case of changing external and internal parameters requires a study of whether there can be a transition from stable to unstable state. So enterprise sustainability management should include a rapid response to threats and risks.

Based on the principle that it is better to prevent a crisis than to eliminate its consequences, the policy of modern business should include the following steps: reducing the level of disparities (paying more attention to only one aspect of sustainable development); the ratio of resource consumption and recovery or renewable changes (for non-renewable); increasing the level of innovation implementation; increasing the level of social and environmental responsibility of the enterprise.

\section{Conclusions}

The scientific novelty of the obtained results is to provide the organizational and informational strategy of sustainable development of the enterprise, the elements of which are the development of a qualitative model of sustainable development strategy taking into account the industry characteristics and the forecasting mechanism using latent variables and the method of private least squares in order to build a PLS-PM model of sustainable development of the enterprise as a complex economic system, which allows to assess the degree of impact specific quantitative and implicit qualitative indicators on a particular phenomenon (sustainable development of the enterprise) by the introduction of explanatory variables.

Therefore, during the calculations to verify the relevance of the PLS-PM model of the sustainable development, it was proved that the tripartite approach, relevant for macroeconomic objects requires specification by highlighting additional aspects (considering the integrative dimension) of sustainable development at the micro level. The proposed component of sustainable development includes the provision and balance of resources, the state of property and an innovation activity. Accordingly it is proposed to include production and technological subsystems that were not taken into account in the components which were mentioned above.

Using the methods of scientific generalization and abstraction the essence of latent variables and the relationship between them was identified and substantiated as well as the numerical modeling was performed. Using the method of abstraction it was possible to seemingly separate the characteristics of sustainable development that are irrelevant for modeling from itself (such as binary indicators for the costs of modernization and implementation of innovations and initiatives to reduce the impact of production on the environment).

\section{References}

1. O.V. Bazhenov, A.D. Galenkova, Razvitie metodiki prognozirovaniya pri modelirovanii kompleksnykh ekonomicheskikh sistem (Development of forecasting techniques for modeling complex economic systems). Ekonomicheskiy analiz: teoriya i praktika 16(3(462)), 573-581 (2017)

2. I. Buzko, O. Vartanova, I. Trunina, I. Khovrak, Theoretical aspects of regional sustainable development in the EU and Ukraine. Innovative Economic Symposium 61, 01001 (2019)

3. A. Diamantopoulos, J. Siguaw, Formative Versus Reflective Indicators in Organizational Measure Development: A Comparison and Empirical Illustration. British Journal of Management 17, 263282 (2006)

4. T.K. Dijkstra, J. Henseler, Consistent and Asymptotically Normal PLS Estimators for Linear Structural Equations, Computational Statistics \& Data Analysis 81(1), 10-23 (2015). doi:10.1016/j.csda.2014.07.008

5. C. Fornell, D.F. Larcker, Evaluating structural equation models with unobservable variables and measurement error. Journal of Marketing Research 18(1), 39-50

(1981). doi:10.1177/002224378101800104

6. J.F. Hair, G.T.M. Hult, C.M. Ringle, M. Sarstedt, $A$ Primer on Partial Least Squares Structural Equation Modeling (PLS-SEM), 2nd edn. (Sage, Thousand Oaks, 2017)

7. D.S. Hazova, Matematicheskoe modelirovanie ustojchivogo razvitija turizma (Mathematical modeling of sustainable tourism development), 2014

8. J. Henseler, T.K. Dijkstra, M. Sarstedt, C.M. Ringle, A. Diamantopoulos, D.W. Straub, D.J. Ketchen, J.F. Hair, G.T.M. Hult, Common Beliefs and Reality About PLS. Organizational Research Methods 17(2), 182-209 (2014)

9. O.I. Maslak, N.Ye. Grishko, O.O. Hlazunova, K.O. Vorobiova, Approaches to the management of the costs of innovation activity of mining enterprises: aspects of economic security. Naukovyi Visnyk Natsionalnoho Hirnychoho Universytetu 5, 137-145 (2017)

10. M.V. Musatov, A.A. L'vov, Analiz modelei metoda naimen'shikh kvadratov i metodov polucheniia otsenok (Analysis of LS models and method of obtaining estimates). Vestnik Saratovskogo gosudarstvennogo tekhnicheskogo universiteta 4(2), 137-140 (2009)

11. R.A. Peterson, Y. Kim, On the Relationship between Coefficient Alpha and Composite Reliability. Journal of Applied Psychology 98(1), 194-198 (2013). doi:10.1037/a0030767

12. F. Schuberth, J. Henseler, T.K. Dijkstra, Confirmatory Composite Analysis. Frontiers in Psychology 9 (2018). doi:10.3389/fpsyg.2018.02541 